\title{
DECAY RESISTANCE OF CEMENT-BONDED ORIENTED STRAND BOARD
}

\author{
Antonios N. Papadopoulos \\ The objective of this study was to evaluate the decay resistance of \\ cement bonded oriented strand board (OSB) against brown (Coniophora \\ puteana) and white rot (Termites versicolor) fungi. Overall, both fungi \\ failed to attack the cement-bonded OSB. Boards made with 3.0 cement- \\ to-wood ratio showed weight gain instead of weight loss. Therefore, it is \\ recommended that cement-bonded OSB is technically suitable for \\ exterior use where both moisture and favourable conditions for fungi \\ development are present.
}

Keywords: Oriented strand board, OSB, Cement, Decay resistance, Coniophora puteana, Termites versicolor

Contact information: Technological Educational Institute of Kavala, Branch of Drama, Department of Forestry and Management of Natural Environment, Laboratory of Wood and Wood Products, Drama, TK 66100,Greece.Email: antonios1974@hotmail.com, antpap@teikav.edu.gr

\section{INTRODUCTION}

Cement-bonded wood composite panels are not a novel concept, having been on the market for over a century. In the past, these panels have consisted of excelsior and magnesite and have been used primarily as low-density insulating materials. By the early 1960's, a high-density cement-bonded structural flakeboard was developed, leading to expanded applications (Deppe 1974). Today, wood-cement panels have found acceptance in a number of countries as a result of certain desirable characteristics. The development and use of wood-cement panels attest to their attraction as building materials. In addition to their resistance to fire, these materials have a special attraction for use in warm, humid climates where decay and termites are a major concern (Jorge et al. 2004). The cement binder provides a durable surface as well as one that can be easily embossed and colored for an alternate, low maintenance finished product. The raw materials used are compatible with a range of processing methods to provide a variety of products that are easily machined with conventional wood-working tools. Although heavier than resin-bonded panels, they are lighter than concrete and, therefore, woodcement panels can replace concrete in construction, namely prefabricated construction, in elements that are not subjected to loads, like walls. These attributes appeal to engineers, architects and contractors for use in public and multifamily residential buildings.

The majority of research in this field has been carried out on particleboards and flakeboards. The focused topics include the problem of the compatibility between cement and wood and ways of overcoming the problem, methods of manufacture and the properties exhibited by common wood-composites, special techniques to accelerate the curing of cement and to improve the properties, and finally manufacture of non-wood raw 
materials - cement composites. An excellent review can be found elsewhere (Jorge et al. 2004).

Recently, oriented strand board (OSB) has been successfully manufactured at laboratory scale, using cement as a binder (Papadopoulos, in press). It was found that an increase of cement-wood ratio resulted to an increase in all strength values, with the exception of rupture. The modulus of elasticity, internal bond strength and thickness swelling values obtained with 2.0 wood-cement ratio conformed to the more stringent requirements of EN 300 for $\mathrm{OSB} / 4$. An important observation was that a lower cementwood ratio was required in order to manufacture acceptable OSB than particleboards and this may be due to the geometry of the strands.

The objective of this paper was to examine the decay resistance of cement-bonded OSB against brown and white rot fungi. This is the first study, as far as the author is aware, that examined the decay resistance of cement-bonded oriented strand board. The issue of durability of cement-bonded particleboard has been recently addressed. Okino and co-workers (2004), found no measurable wood degradation (weight loss) in cementbonded particleboards made with 2.0 or higher cement-to-wood ratio, exposed to the attack of Gloeophyllum trabeum and Trametes versicolor. Tests conducted by Pirie et al. (1990) suggested that conventionally made cement-bonded particleboards are very resistant to the attack of the white rot fungus Pleurotus ostreatus and to the brown rot fungus Coniophra puteana.

\section{EXPERIMENTAL}

\section{OSB Manufacture}

Aspen ring-cut strands (Populus alba) were used in this study, with average strand size of $75 \mathrm{~mm} \times 20 \mathrm{~mm} \times 0.75 \mathrm{~mm}$ (length $\mathrm{x}$ width $\times$ thickness). The strands were air-dried to approximately $10 \%$ moisture content (MC). The bonding agent employed was commercial grade Portland cement, type I. Ammonium chloride $\left(\mathrm{NH}_{4} \mathrm{Cl}_{2}-2 \%\right.$ based on weight of cement) was introduced into cement slurry to accelerate cement set during hydration. A predetermined amount of air-dried strands and an ammonium chloride (anhydrous) distilled water solution were thoroughly blended. Cement was subsequently added and the constituents were mixed until the cement paste completely hydrated. The quantity of distilled water added, was calculated using a relationship developed by Simatumpang (1979) and applied by other researchers as well (Jones et al. 1985; Moslemi and Pfister 1987; Fuwape 1995; Sudin et al. 1995). In his formulation, the water requirement was determined as follows:

where:

$$
\text { water }(\text { litres })=0.35 \mathrm{C}+(0.30-\mathrm{MC}) \mathrm{W}
$$

$\mathrm{C}=$ cement weight $(\mathrm{kg})$

$\mathrm{MC}=$ wood strands moisture content (oven-dry basis)

$\mathrm{W}=$ oven-dry wood strand weight $(\mathrm{kg})$. 
After 15 minutes of manual mixing, the cement-wood water mixture was screened onto a caul. The mat was evenly distributed to provide as uniform a density as possible and pre-pressed to a thickness of approximately $50 \mathrm{~mm}$. Cold pressing took place under an initial pressure of $2-5 \mathrm{MPa}$, depending on the cement-to-wood ratio to a $16 \mathrm{~mm}$ thickness, after which the board was retained in compression for 24 hours. Target board density was $1000 \mathrm{Kg} / \mathrm{m}^{3}$. Two replicates of each board were made at cement-wood ratios of 3.0, 2.0, and 1.5 (by weight), giving a total of 6 boards. To minimize cement capillary desiccation and enhance hydration, boards were misted with distilled water, then wrapped in cellophane before storing for curing at $20^{\circ} \mathrm{C}$ and $65 \%$ relative humidity for a month.

\section{Decay Tests}

Samples were packed in an argon atmosphere and sterilised by irradiation $(2.5$ Mrad.) prior to decay tests, using the methods described in DD ENV 12038:1996. Laboratory pure strains of the brown rot fungi Coniophora puteana (No FPRL 11E) and white rot fungi Termites versicolor (CTB 863A) were used, grown on malt agar. Blocks were planted on sterile specimen supports placed on the cultures of the test fungus actively growing on $5 \%$ malt agar in $500 \mathrm{ml}$ capacity jars. An additional set of sterile control samples were used to assess operational control losses. The closed jars were incubated for 16 weeks, at $22+/-1{ }^{0} \mathrm{C}$ and $75+/-5 \%$ relative humidity to evaluate the efficacy of the treatments. After incubation, the samples were removed from the jars, cleaned, weighed, conditioned to constant weight as above and re-weighed. Weight loss (WL) was expressed as a percentage of the initial weight of the sample. Weight losses from sterile controls were subtracted from the decay results to give corrected data.

\section{RESULTS AND DISCUSSION}

The results obtained after a 16-week incubation period are presented in Table 1. Overall, both fungi failed to attack the cement-bonded OSB. Visual examination revealed a slight presence of mycelium in the surface of the tested samples. Similar observation has also been made by Okino et al. (2004) in cement-bonded particleboards made from eucalypt and rubber wood particles. Boards made with 3.0 cement-to-wood ratio showed weight gain instead of weight loss. This, according to de Souza and coworkers (1997), was a consequence of the final curing process of the cement, at these high cement-wood ratios. Investigation of cement-bonded panels is not very common. Tests conducted by Dinwoodie and Paxton (1991) and Pirie et al. (1990) suggested that conventionally made cement-bonded particleboards are very resistant to the attack of the white rot fungus Pleurotus ostreatus and to the brown rot fungus Coniophra puteana. Similar results were also reported by Okino et al. $(2004 ; 2005)$ in cement-bonded boards made from eucalypt or cypress particles. However in that case, fungi tests were conducted according to the ASTM D 2017-8, where the exposure to fungi period is 12 weeks. The present study was the first study, as far as the authors are aware, that examined the decay resistance of OSB using cement as a binder. 
Table 1. Weight loss (WL) of cement-bonded OSB. (Standard deviations in parentheses - Each value is the mean of eight samples).

\begin{tabular}{|c|c|c|}
\hline & Brown rot & White rot \\
\hline Cement : Wood & WL (\%) & WL (\%) \\
\hline 1.5 & 5.25 & 7.33 \\
\hline 2.0 & $0.72(0.06)$ & $3.24(0.55)$ \\
\hline 3.0 & $-3.21(0.59)$ & $-2.22(0.7)$ \\
\hline Commercial OSB & $11.22(2.11)$ & $28.25(3.21)$ \\
\hline
\end{tabular}

\section{CONCLUSIONS}

1. Both fungi used in this work failed to attack the cement-bonded oriented strand boards.

2. Boards made with 3.0 cement-to-wood ratio showed weight gain instead of weight loss.

3. It is recommended that cement-bonded OSB is technically suitable for exterior use where both moisture and favourable conditions for fungi development are present.

\section{REFERENCES CITED}

de Souza, M. R., Geimer, R. L., Moslemi, A. A. (1997). "Degradation of conventional and $\mathrm{CO}_{2}$ injected cement-bonded particleboard by exposure to fungi and termites," $J$. Tropical Forest Products 3, 63-69.

Deppe, H. J. (1974). "On the production and application of cement-bonded wood chipboards", Proceedings of the $8^{\text {th }}$ Washington State Symposium on Particleboard, 267-286.

Dinwoodie, J. M., Paxton, B. H. (1991). "The long term performance of cement-bonded particleboard," in: Inorganic Bonded Wood and Fiber Materials, ${ }^{\text {nd }}$ International Conference, Moscow, 45.

Fuwape, J. A. (1995). "The effect of cement-wood ratio on the strength properties of cement-bonded particleboard from spruce," J. Tropical Forest Products 1, 49-58.

Johns, W. E., Rammon, R. M., Youngquist, J. (1985). "Chemical effects of mixed hardwood furnish on panel properties," Proceedings of the $19^{\text {th }}$ Washington State Symposium on Particleboard, 363-377.

Jorge, F. C., Pereira, C., Ferreira, J. M. F. (2004). "Wood-cement composites: a review," Holz als Roh-und Werkstoff 62, 370-377.

Moslemi, A. A., Pfister, S. C. (1987). "The influence of cement-wood ratio and cement type on bending strength and dimensional stability of wood-cement composite panels," Wood Fiber Sci. 19, 165-175. 
Okino, E. Y. A., de Souza, M. R., Santana, M. A. E., Alves, M. V., de Souza, M. E., and Teixeira, D. E. (2004).“Cement-bonded wood particleboard with a mixture of eucalypt and rubberwood," Cement \& Concrete Composites 26, 729-734.

Okino, E. Y. A., de Souza, M. R., Santana, M. A. E., Alves, M. V., de Souza, M. E., and Teixeira, D. E. (2005). "Physico-mechanical properties and decay resistance of Cupressus spp cement bonded particleboards," Cement \& Concrete Composites 27, 333-338.

Papadopoulos, A. N. (in press). "Mechanical and physical properties of cement-bonded OSB", Holz als Roh-und Werkstoff.

Pirie B. J., Glasser, F. P., Schmitt-Henco, C., and Akers, S. A. S. (1990). "Durability studies and characterisation of the matrix and fibre-cement interface of asbestos-free fibre-cement products," Cement \& Concrete Composites 12, 233-234.

Simaturpang, M. H. (1979). "The water requirements of manufactured cement-bonded particleboard," Holz als Roh-und Werkstoff 37, 379-382.

Sudin, R., Shaari, K., and Selamat, S. (1995) "Cement-bonded particleboard from presoaked oil palm trunk: effects of particle size and chemical additive," J. Tropical Forest Products 1, 71-77.

Article submitted: May 16, 2006; Revision accepted: July 14, 2006; Published: July 15, 2006 